Ananda Galuh P., Cindy Claudia Radha A., Erika Rahma S..

\title{
SISTEM INFORMASI MANAJEMEN DALAM UPAYA PENINGKATAN DAYA SAING INDUSTRI KERAJINAN RUMAH TANGGA
}

\author{
Ananda Galuh P., Cindy Claudia Radha A., Erika Rahma S. \\ Prodi Akuntansi/Fakultas Ekonomi/ Universitas Tulungagung
}

\begin{abstract}
Most of the obstacles or problems that are most often experienced by household craft craftsmen are in terms of marketing or marketing management. Where the marketing they do is still very traditional. In a sense, they trade manually i.e. go to the market and offer their products to customers directly. E-commerce (Electronic Commerce) or in Indonesian Electronic Commerce is the activity of distributing, selling, purchasing, marketing products (goods and services), by utilizing telecommunications networks such as the internet, television, or other computer networks. The purpose of this research is to solve various problems in business which include services, product costs, and business strategies. This whole system is used in order toanalyze other information systems on the implementation of an organization's operational activities.

The case study used in this research is a market expansion approach using target marketing opportunity analysis, system model design, customer interface facilities, market communication and implementation design. The research instrument used interview and observation techniques as well as literature study. Sampling using purposive sampling technique. The data of this study were obtained from primary data and secondary data. The design of the application is to use the Waterfall approach. This approach is a classic model and is systematic so that it is easy to understand because all the processes work sequentially in the stages of building a software.

The results of this study were carried out with several research methods, namely the Black Box method and User Acceptance. Black Box testing is a test with the system only observing the results of execution through test data and checking the functionality of the software, while the User Acceptance method is a testing process carried out by users which is intended to produce documents that will be used as evidence that the software or software used and developed has been accepted. by the user.
\end{abstract}

Keywords: Management Information System, E-commerce, Handicraft Industry. 


\begin{abstract}
Abstrak
Kebanyakan kendala atau permalahan yang paling sering dialami oleh para pengrajin kerajinan rumah tangga adalah dalam hal pengelolaan marketing atau pemasaran. Dimana pemasaran yang mereka lakukan masih sangat bersifat tradisional. Dalam artian, mereka melakukan perdagangan secara manual yaitu pergi ke pasar dan menawarkan produk mereka kepada pelanggan secara langsung. E-commerce (Elektronik Commerce) atau dalam bahasa Indonesia Perdagangan Secara Elektronik adalah aktivitas penyebaran, penjualan, pembelian, pemasaran produk (barang dan jasa), dengan memanfaatkan jaringan telekomunikasi seperti internet, televisi, atau jaringan komputer lainnya. Tujuan dari diadakannya penelitian ini yaitu untuk memecahkan beragam masalah dalam bisnis yang meliputi layanan, biaya produk, serta strategi bisnis. Keseluruhan sistem ini digunakan dalam rangka menganalisis sistem informasi yang lain pada penerapan aktivitas operasional suatu organisasi.

Studi kasus yang digunakan pada penelitian ini adalah dengan pendekatan perluasan pasar menggunakan analisa kesempatan sasaran pemasaran, perancangan model sistem, fasilitas antar muka pelanggan, komunikasi pasar dan rancangan implementasi. Instrumen penelitian menggunakan teknik wawancara dan observasi serta studi pustaka. Pengambilan sampel menggunakan teknik purposive sampling. Data penelitian ini didapatkan dari data primer dan data sekunder. Perancangan aplikasinya yaitu dengan menggunakan pendekatan Waterfall. Pendekatan ini merupakan model klasik dan bersifat sistematis sehingga mudah dalam memahaminya karena semua prosesnya bekerja secara berurutan dalam tahapan membangun sebuah perangkat lunak.

Hasil dari penelitian ini dilakukan dengan beberapa metode penelitian yaitu dengan metode Black Box dan User Acceptance. Pengujian Black Box adalah pengujian dengan sistem hanya mengamati hasil eksekusi melalui data uji dan memeriksa fungsi dari software, sedangkan metode User Acceptance adalah proses pengujian yang dilakuan pengguna yang dimaksudkan untuk menhasilkan dokumen yang akan dijadikan bukti bahwa software atau perangkat lunak yang digunakan dan dikembangkan telah diterima oleh pengguna.
\end{abstract}

Kata Kunci : Sistem Informasi Manajemen, E-commerce, Industri Kerajinan. 


\section{PENDAHULUAN}

Teknologi informasi yang berkemmbang saat ini dapat menjadikan semua hal menjadi lebih rinci, rapi, cepat dan tepat. Pengelolaan proses penjualandan pembeliandapat dilakukan secara terkomputerisasi yang sistematis dan membuat proses manajemen pemasaran dapat meningkatkan daya saing industri. Akan tetapi terkadang kesesuaian kualitas dan kuantitas dari produk yang diperjual belikan tidak sesuai dengan ekspektasi pembeli dengan barang telah dibeli. Bahkan belakangan ini sering terjadi kasus seperti itu yang bisa menimbulkan kekecewaan dari para pembeli. Adapun selain kualitas dan kuantitas, keamanan produk pun terkadang menjadi salah satu pemicu kekecewaan pembeli. Hal ini dikarenakan, ketika barang sampai di ekspedisi pihak ekspedisi terkadang tidak memperlakukan barang-barang tersebut dengan baik. Alhasil tidak jarang pula para pembeli mendapati produk pesanannya dalam keadaan pecah. Terdapat satu cara yang dapat digunakan dalam menekan tingkat ketidakpastian tersebut dengan mendatangi secara langsung pihak penjual seperti yang dilakukan oleh web e-commerce Shopee. Namun apabila jarak antara penjual dengan pembeli saling berjauhan, hal tersebut juga mustahil untuk dilakukan. Berbeda dengan aplikasi atau web e-commerce bukalapak.com mereka menyediakan fasilitas tawar menawar setiap produk yang diperjualbelikan meskipun hanya lewat teks. Sistem informasi manajemen yang akan dibangun nantinya memiliki fasilitas video call. Kelemahan para pengrajin kerajinan rumah tangga atau juga bisa disebut dengan crafter adalah dalam hal pengelolaan marketing atau pemasaran. Dimana pemasaran yang mereka lakukan masih sangat bersifat tradisional. Dalam artian, mereka melakukan perdagangan secara manual yaitu pergi ke pasar dan menawarkan produk mereka kepada pelanggan secara langsung.

Sementara orang-orang yang mungkin berada diwilayah yang jauh sedang membutuhkan produk kerajinan tangan, entah digunakan untuk souvenir, buah tangan dan oleh-oleh, atau bahkan untuk dikoleksi sendiri. Padahal dengan sistem perdagangan yang seperti itu sangat mempengaruhi jumlah penjumlahan produk mereka. Hal tersebut jelas merugikan mereka, melihat hal tersebut sebenarnya merupakan sebuah keterbatasan yang perlu dikaji ulang dengan tujuan mengembangkan industri kerajinan rumah tangga tersebut. Dengan adanya kemajuan tekhnologi seperti pada saat ini, pengelolaan produk-produk yang akan dipasarkan oleh para pengrajin dapat terbantu dengan sistem informasi manajemen yang berbasis e-commerce atau sering disebut online.Pembangunan Sistem Informasi Manajemen digunakan untuk Meningkatkan Daya Saing Industri Rumah Tangga, Selain dapat melihat 
barang dagangan secara langsung barang yang dipasarkan (dalam bentuk video atau video call), pembeli juga dapat berbicara secara tatap muka dengan penjual, menjadikan sistem informasi manajemen berbasis e-commerce layaknya dipasar umum. Para pengrajin yang memasarkan barang dagangannya juga bisa memanfaatkan rincian transaksi perdagangan yang mereka dagangkan. Tujuan dari penelitian ini adalah mengurangi berbagai resiko pemasaran online atau E-Commerce bagi masyarakat untuk melihat secara langsung barang dagangan yang dipasarkan dan dapat melakukan tatap muka baik untuk diskusi maupun tawar menawar dengan penjual. Pengelolaan pada proses perdagangan secara terkomputerisasi melalui sistem informasi manajemen.

\section{LANDASAN TEORI}

\section{SISTEM INFORMASI MANAJEMEN}

\section{Pengertian Sistem Informasi Manajemen}

Sistem informasi manajemen kerap disingkat dengan SIM yang berasal dari bahasa Inggris yakni management information system. Pengertian SIM adalah sistem perencanaan bagian dari pengendalian internal dalam bisnis yang terdiri atas pemanfaatan dokumen, manusia, teknologi, serta prosedur dalam akuntansi manajemen. Menurut dari ahli yang bernama Yakub (2012) sistem informasi merupakan sebuah kombinasi atau gabungan yang teratur dan terorganisir antara individu perangkat keras (hardware), perangkat lunak (software), jaringan komunikasi (network communication) dan sumber daya yang dikumpukan (collecting), modifikasi (modification), dan melakukan penyebaran informasi (broadcast).

Tujuannya adalah memecahkan beragam masalah dalam bisnis yang meliputi layanan, biaya produk, serta strategi bisnis. Keseluruhan sistem ini digunakan dalam rangka menganalisis sistem informasi yang lain pada penerapan aktivitas operasional suatu organisasi. Pengembangan sistem (systems development) merupakan penyusun suatu sistem yang baru untuk menggantikan sistem yang lama secara keseluruhan atau memperbaiki sistem yang telah ada. (Yanna \& Fortunella;2015 dalam makalah pengembangan sistem).

Menurut Ahmad dan Munawir (Ahmad \& Munawir, 2018), tujuan dari sistem informasi manajemen itu sendiri adalah untuk mencapai situasi di mana data dan fakta diproses setelah diterima, dan informasi diperoleh pada waktu yang tepat, sehingga arti yang 
positif. Efek dalam pengambilan keputusan. Oleh karena itu, Sistem Informasi Manajemen mempunyai fungsi-fungsi utama, yaitu:

1. Kartu SIM adalah sistem yang mengintegrasikan manusia dan mesin

2. Desain dan implementasi SIM dapat menampilkan informasi yang dibutuhkan

3. SIM digunakan untuk mendukung fungsi operasional manajemen dan pengambilan keputusan manajemen dalam organisasi.

Ahmad dan Munawir (Ahmad \& Munawir, 2018) menyatakan bahwa SIM memiliki beberapa fitur utama, yaitu:

1. SIM berjalan pada tugas-tugas terstruktur, seperti prosedur kerja, keputusan manajemen, akurasi sistem informasi, format laporan, dll.

2. SIM bertujuan untuk meningkatkan efisiensi dan efektivitas kerja serta mengurangi biaya.

3. SIM dapat membantu karyawan memberikan laporan untuk pengambilan keputusan manajemen.

4. SIM dapat memfasilitasi akses ke informasi saat manajemen membutuhkannya. Beberapa ahli memberikan pendapatnya terkait dengan pengertian dari SIM. Diantaranya:

\section{- Bodnar dan Hopwood}

Management information system adalah kumpulan perangkat keras dan perangkat lunak yang dirancang untuk mentrasformasikan data dalam bentuk informasi yang berguna. (Accounting Information System)

\section{- L. JamersHavery}

Managementinformationsystem adalah prosedur logis dan rasional untuk melakukan atau merancang suatu rangkaian komponen yang berhubungan satu sama lain.

\section{- Azhar Susanto}

Sistem informasi manajemen merupakan kumpulan atau grup dari sub sistem atau bagian atau komponen apapun biak fisik maupun non fisik yang saling berhubungan satu sama lain dan berkenaan dengan pengendalian, pengevaluasian, dan perbaikan berkelanjutan.

\section{- LudwigVonBatalanfy}

Management information system merupakan seperangkat unsur yang saling terkait dalam suatu antar relasi diantara unsur unsur tersebut dengan lingkungan. 


\section{Fungsi Sistem Informasi Manajemen}

Banyak manfaat dan fungsi dari sistem informasi manajemen. Fungsi dari sistem ini tidak terbatas pada pihak manajemen saja, melainkan juga bagi organisasi secara keseluruhan. Ulasannya akan dibahas lebih lanjut di bawah ini:

1. Meningkatkan produktivitas serta penghematan dalam hal biaya di dalam organisasi

2. Meningkatkan kualitas dari SDM dikarenakan unit sistem kerja akan lebih terkoordinasi serta sistematis

3. Mempermudah pihak manajemen dalam melakukan pengawasan, perencanaan, pengarahan serta pendelegasian kinerja pada semua departemen yang mempunyai koordinasi dan hubungan.

4. Meningkatkan efisiensi serta efektivitas data yang lebih realtime dan akurat.

\section{Manfaat Sistem Informasi Manajemen}

SIM memiliki beberapa manfaat yang penting dalam keberlangsungan organisasi atau perusahaan, diantaranyaadalah:

1. Menyediakan informasi yang digunakan dalam penghitungan harga pokok produk, jasa, serta tujuan lain yang diinginkan oleh manajemen.

2. Menyediakan informasi yang digunakan untuk merencanakan, mengendalikan, mengevaluasi, serta melakukan perbaikan yang berkelanjutan.

3. Menyediakan informasi dalam mengambil keputusan penting.

\section{Kategori Sistem Informasi Manajemen}

\section{A. Executive Information System (EIS):}

Manajemen senior menggunakan EIS untuk membuat keputusan yang memengaruhi seluruh organisasi. Eksekutif membutuhkan data dengan tingkat akurasi yang tinggi dan kemampuan untuk menelusuri data tersebut.

\section{B. Marketing Information System (MkIS):}

Tim pemasaran menggunakan MkIS untuk melaporkan efektivitas histori proses pemasaran dan saat ini. Juga menggunakannya sebagai data yang dianalisa untuk merencanakan proses pemasaran di masa depan.

C. Business Intelligence System (BIS): 
Operasi yang menggunakan BIS biasanya untuk membuat keputusan bisnis berdasarkan pengumpulan, integrasi, dan analisis data dan informasi yang dikumpulkan. Sistem ini mirip dengan EIS, tetapi manajer dan eksekutif tingkat bawah menggunakannya.

D. Customer Relationship Management System (CRM):

Sistem CRM menyimpan informasi penting tentang pelanggan, termasuk penjualan sebelumnya, informasi kontak, dan peluang penjualan. Tim pemasaran, layanan pelanggan, penjualan, dan pengembangan bisnis sering menggunakan CRM.

E. Sales Force Automation System (SFA):

Komponen khusus sistem SFA yang mengotomatiskan banyak tugas yang dilakukan oleh tim penjualan. Ini dapat mencakup manajemen kontak, pelacakan dan pembuatan kontak, dan manajemen pesanan.

\section{F. Transaction Processing System (TPS):}

Pada tingkat dasar, TPS dapat berupa sistem point of sale (POS) seperti Mokapos, atau sistem yang memungkinkan wisatawan untuk mencari hotel dan termasuk opsi kamar lalu seperti kisaran harga, jenis dan jumlah tempat tidur. Karyawan dapat menggunakan data yang dibuat untuk melaporkan tren penggunaan dan melacak penjualan dari waktu ke waktu.

G. Knowledge Management System (KMS):

Layanan pelanggan dapat menggunakan sistem KMS untuk menjawab pertanyaan dan memecahkan masalah.

\section{H. Financial Accounting System (FAS):}

Sistem ini khusus untuk departemen yang berhubungan dengan keuangan dan akuntansi, seperti untuk menghitung hutang dagang (AP) dan piutang dagang (AR). Contoh software akuntansi terbaik yang bisa Anda pakai adalah seperti $\underline{\text { Accurate }}$ Online.

\section{Human Resource Management System (HRMS):}

Sistem ini melacak catatan kinerja karyawan dan data penggajian.

\section{J. Supply Chain Management System (SCM):}

Perusahaan manufaktur menggunakan SCM untuk melacak aliran sumber daya, bahan, dan layanan dari pembelian hingga produk akhir dikirim.

\section{Jenis Laporan yang Dihasilkan}




\section{A. Dijadwalkan}

Dibuat secara berkala, laporan ini menggunakan aturan yang disediakan pemohon untuk menarik dan mengatur data. Laporan terjadwal memungkinkan perusahaan untuk menganalisis data dari waktu ke waktu (contoh: Sebuah maskapai penerbangan dapat melihat persentase bagasi yang hilang berdasarkan bulan), lokasi (contoh: Distributor dapat membandingkan angka penjualan dari toko yang berbeda), atau parameter lainnya.

\section{B. Ad-hoc}

Ini adalah laporan satu kali yang dibuat pengguna untuk menjawab pertanyaan. Jika laporan berguna, Anda dapat mengubah laporan ad-hoc menjadi laporan terjadwal.

\section{Real-time}

Jenis laporan ini memungkinkan seseorang untuk memonitor perubahan saat terjadi. Misalnya, kepala costumerservice dapat melihat lonjakan volume panggilan yang tidak terduga dan menemukan cara untuk meningkatkan produktivitas atau mengecek beberapa panggilan di tempat lain.

\section{E-COMMERCE}

\section{Pengertian E- Commerce}

E-commerce (Elektronik Commerce) atau dalam bahasa indonesia Perdagangan Secara Elektronik adalah aktivitas penyebaran, penjualan, pembelian, pemasaran produk (barang dan jasa), dengan memanfaatkan jaringan telekomunikasi seperti internet, televisi, atau jaringan komputer lainnya.Secara sederhana e-commerce adalah proses pembelian maupun penjualan produk secara elektronik. e-commerce sendiri makian kian berkembang beberapa tahun belakangan ini dan secara perlahap menggantikan toko tradisional ( Offline ). Menurut Rahmati (2009) E-commerce singkatan dari Electronic Commerce yang artinya sistem pemasaran secara atau dengan media elektronik. E-Commerce ini mencakup distribusi, penjualan, pembelian, marketing dan service dari sebuah produk yang dilakukan dalam sebuah system elektronika seperti Internet atau bentuk jaringan komputer yang lain.

\section{Manfaat E-Commerce}

\section{A. Menemukan titik buta / celah pasar dengan cepat}

Hadirnya e-commerce tentu dapat memperjelas celah pasar bagi bisnis. Data dan informasi pengguna website e-commerce dapat mempengaruhi keputusan bisnis 
perusahaan. Jika kamu benar-benar bisa membaca informasi dari data e-commerce dan dapat membuat keputusan berdasarkan data, bukan tidak mungkin bisnis kamu akan berkembang.

\section{B. E-commerce sebagai personal shopperassistance}

Manfaat e-commerce bukan lagi sekadar menjadi pengganti toko offline. Lebih dari itu. Kini, e-commerce sudah menjadi personal shopperassistant. Hadirnya fitur notifikasi via email sebagai pengingat mulai dari barang yang masuk kedalam wishlist calon pembeli, produk rekomendasi, sampai dengan pengumuman diskon atau promo yang sedang berlangsung. hadirnya fitur notifikasi via email, atau push notification di smartphone, sedikit banyak memaksa pengunjung untuk melihat tawaran menarik di website e-commerce.

\section{Menghemat waktu lebih baik}

Kini transaksi jual beli produk tidak harus dilakukan secara konvensional atau mendatangi toko fisik. Anda bisa menggunakan e-commerce menjadi media digital yang bisa menghubungan pebisnis dengan konsumen secara langsung. Tentu waktu yang Anda miliki bisa dimanfaatkan untuk kegiatan lain yang lebih produktif. Pelanggan setia tidak perlu menghabiskan waktu lebih lama untuk mengantri atau membeli produk secara manual.

\section{Menjadi bisnis lintas wilayah}

Manfaat e-commerce bisa menghadirkan solusi penjualan produk tanpa terpengaruh batas wilayah. Kemudahan e-commerce yang mengandalkan teknologi dan bisa mengirim barang via ekspedisi sangat menguntungkan dua belah pihak. Ekspansi usaha secara internasional atau lintas negara bisa terwujud berkat $e$-commerce ini.

\section{E. Menawarkan fleksibilitas yang tinggi}

Manfaat e-commerce bagi usaha Anda adalah penawaran fleksibilitas tinggi untuk konsumen. Konsumen tidak memiliki batasan waktu dan larangan untuk melihat katalog produk kapan saja. Mereka bebas melakukan order dengan waktu 24 jam penuh setiap hari. E-commerce bisa menjadi tempat untuk menghadirkan variasi atau pilihan produk yang tidak terbatas.

\section{F. Mengembangkan bisnis yang lebih besar}

Jangkauan yang sangat luas dengan proses pengiriman yang cepat menjadi tren jual beli di era digital. Anda yang ingin mengembangkan bisnis menjadi lebih besar, sahsah saja. Gunakan dan manfaatkan e-commerce untuk mencapai tujuan usaha Anda. 
Adanya e-commerce bisa meningkatkan sistem promosi dan branding usaha Anda lebih baik lagi.

\section{Jenis-jenis E- Commerce}

\section{- Business to business (B2B)}

Jenis di mana sebuah perusahaan menjual produk atau jasa kepada perusahaan lainnya. Dalam model e-commerce ini, biasanya pembeli memesan barang dalam jumlah besar. Contohnya adalah sebuah perusahaan yang membeli perlengkapan kantor dari sebuah produsen.

- Business to Consumer (B2C)

Dalam jenis e-commerce ini, sebuah perusahaan menjual produk atau jasa kepada konsumen. Pada umumnya, pelanggan dalam e-commerce $\mathrm{B} 2 \mathrm{C}$ hanya mengecer. Jika anda pernah membeli dari suatu toko online, aktivitas tersebut termasuk dalam golongan ini.

- Consumer to Consumer (C2C)

Pernah menjual barang bekas ke orang lain yang membutuhkannya melalui internet? Aktivitas tersebut termasuk dalam e-commercejenis ini. Dengan kata lain, C2C adalah transaksi online antara dua individu.

\section{- Consumertobusiness (C2B)}

Berkebalikan dengan $\mathrm{B} 2 \mathrm{C}$, e-commerce $\mathrm{C} 2 \mathrm{~B}$ adalah skenario di mana seseorang menjual produk atau layanan kepada sebuah perusahaan. Seorang graphic designer, misalnya, menawarkan dan menjual logo buatannya kepada sebuah bisnis makanan.

- Business topublicadministration (B2A)

Model ecommerce ini mirip dengan B2B, tetapi pelakunya adalah bisnis dan lembaga pemerintah. Contoh B2A adalah jasa pembuatan website untuk sistem administrasi online.

\section{- Consumer to Public Administration (C2A)}

Jenis e-commerce ini berjalan seperti C2B. Namun, transaksi dilakukan oleh individu dan lembaga pemerintah. E-commerce dengan model $\mathrm{C} 2 \mathrm{~A}$ jarang ditemui di Indonesia. Jenis transaksi yang terjadi biasanya berbentuk jasa.

Mengimplementasikan sebuah sistem E-Commerce tidak semudah atau sekedar mempergunakan sebuah perangkat aplikasi baru, namun lebih kepada pengenalan sebuah prosedur kerja baru (transformasi bisnis). Tentu saja perubahan 
yang ada akan mendatangkan berbagai permasalahan, terutama yang berhubungan dengan budaya kerja dan relasi dengan rekanan maupun pelanggan (Fingar, 2000):

1. Sistem E-Commerce melibatkan arsitektur perangkat lunak dan perangkat keras yang akan terus berkembang sejalan dengan kemajuan teknologi, sehingga strategi pengembangan dan penerapannyapun akan berjalan seiring dengan siklus hidup perusahaan; dan

2. Mengembangkan sistem E-Commerce secara perlahan dan bertahap secara tidak langsung menurunkan tingginya resiko kegagalan implementasi yang dihadapi perusahaan.

\section{Metode Pembayaran E-Commerce}

Beberapametode yang sering digunakan dalam E-Commerce, yaitu :

\section{- Pembayaran Elektronik}

Pembayaran dengan metode ini menggunakan internet banking, kartu kredit/debit, atau dengan uang digital yang sudah beredar seperti Go-Pay, Ovo, Link aja, Dana, Dan lainnya.

\section{- Pembayaran Cash On Delivery ( COD )}

Transaksi pembayaran dengan metode ini dilakukan secara langsung. Jadi Penjual dan Pembeli akan bertemu sesuai dengan kesepakatan ( bisa juga dengan bantuan perantara kurir ), setelah menerima barang, pembeli membayarkan uang secara tunai kepada pihak Penjual. Pembayaran menggunakan metode ini juga dapat meminimalisir terhadap penipuan secara online.

\section{- Pembayaran lewat Transfer}

Pihak pembeli akan mentransfer sejumlah uang ke nomor rekening penjual. setelah membayar, barang baru akan dikirim oleh penjual melalui jasa pengiriman.

\section{INDUSTRI KERAJINAN}

\section{Pengertian Industri Kerajinan}

Industri adalah usaha untuk mengolah bahan mentah hingga menjadi barang setengah jadi ataupun barang jadi. Sementara itu, kerajinan didefinisikan sebagai barang yang 
dibuat dengan menonjolkan fungsi untuk dipakai maupun sebagai unsur dekoratif yang memiliki nilai estetika.

Dapat disimpulkan bahwa industri kerajinan adalah setiap usaha untuk mengubah bahan mentah atau bahan baku menjadi produk yang memiliki fungsi pakai dan fungsi hias. Yang dimaksud fungsi pakai adalah manfaat yang didapatkan dari suatu barang kerajinan jika barang tersebut digunakan untuk membantu pekerjaan kita. Contohnya adalah peralatan rumah tangga, furnitur, dan lain-lain. Industri kerajinan menurut Departemen Perindustrian (1992), industri kerajinan sebagai sumber ekonomi yang diselenggarakan oleh keluargakeluarga, umumnya terpusat di daerah-daerah pedesaan yang tergolong rendah. Produktivitas kerja para pekerja industri masih sangat rendah, apalagi indsutri kerajinan bila dibandingkan dengan industri beasar dan sedang.

\section{Jenis-jenis Industri Kerajinan}

\section{Industri Kerajinan Tanah Liat}

Kerajinan dari tanah liat merupakan industri yang jumlah dan jenis produknya sangat banyak. Selain mudah didapat, tanah liat juga mudah dibentuk tanpa harus menggunakan mesin yang canggih. Contoh kerajinan tanah liat adalah gerabah dan keramik, seperti pot dan vas bunga, teko, aneka wadah, celengan, dan sebagainya.

\section{Industri Kerajinan Kayu/Bambu}

Kayu dan bambu adalah bahan alami yang sangat mudah ditemukan di Indonesia sehingga industri barang kerajinan dari kedua bahan ini juga maju pesat. Jenis kayu yang banyak digunakan adalah kayu jati, mahoni, pinus, dan lainnya. Contoh barang kerajinan kayu dan bambu adalah furnitur, ukiran, kap lampu, patung, dan lain-lain.

\section{Industri Kerajinan Serat Alam}

Melalui proses kreatif, serat alami yang didapat dari hewan maupun tumbuhan bisa diubah menjadi produk kerajinan. Contohnya adalah kepompong ulat sutra, kapuk, eceng gondok, pelepah pisang, nanas, pandan, rami, sabut kelapa, dan kulit jagung. Produk yang dihasilkan bisa berupa kain/pakaian, tas, dompet, taplak meja, bunga hias, boneka, bantal, dan masih banyak lagi.

\section{Industri Kerajinan Logam}

Bahan logam juga banyak dipilih untuk membuat barang-barang kerajinan karena memiliki kelebihan yaitu tahan lama dan tidak mudah lapuk, rusak, atau pecah seperti kayu, serat alam, maupun tanah liat. Tekstur logam yang kokoh, antikarat, dan 
mengilap membuat barang-barang kerajinan dari logam biasanya relatif mahal.Contoh jenis industri ini adalah industri kerajinan tembaga kuningan, emas, perak, dan perunggu. Produk yang dibuat dari logam bisa berupa barang yang memiliki fungsi pakai, seperti peralatan makan, perabot dapur, dan perhiasan, maupun benda-benda dekoratif, misalnya pajangan, patung, kaligrafi, ukiran, dan hiasan dinding.

\section{Industri Kerajinan Batu}

Meskipun masih tergolong jarang, batu juga bisa digunakan untuk membuat barang kerajinan. Kebanyakan barang-barang kerajinan dari batu lebih bersifat dekoratif seperti hiasan di dalam atau luar ruangan, tetapi ada juga yang berupa barang yang dapat dipakai, misalnya pot bunga.

\section{Industri Kerajinan Barang Bekas}

Seiring dengan kepedulian terhadap lingkungan yang makin tinggi, pemanfaatan barang bekas untuk menghasilkan produk yang bernilai guna juga semakin banyak dilakukan. Contoh produknya adalah tas dari plastik kemasan, meja dan kursi dari botol plastik, vas bunga dari kaleng, tempat lilin dari botol kaca, dan sebagainya.

\section{METODE PENELITIAN}

Studi kasus yang digunakan pada penelitian ini adalah dengan pendekatan perluasan pasar menggunakan analisa kesempatan sasaran pemasaran, perancangan model sistem, fasilitas antar muka pelanggan, komunikasi pasar dan rancangan implementasi. Instrumen penelitian menggunakan teknik wawancara dan observasi serta studi pustaka. Pengambilan sampel menggunakan teknik purposive sampling. Data penelitian ini didapatkan dari data primer dan data sekunder. Perancangan aplikasinya yaitu dengan menggunakan pendekatan Waterfall. Pendekatan ini merupakan model klasik dan bersifat sistematis sehingga mudah dalam memahaminya karena semua prosesnya bekerja secara berurutan dalam tahapan membangun sebuah perangkat lunak.

Tahapan penerapan e-commerce dilakukan melalui kegiatan survei, analisis, perancangan, pembuatan sistem, implementasi dan pemeliharaan. Survei ini bertujuan untuk mengetahui ruang lingkup keperluan pasar berdasarkan kebutuhan. Analisis bertujuan untuk memahami sistem yang ada, dengan mengidentifikasi masalah dan memecahkannya menjadi solusi. Perancangan bertujuan mendesain sebuah sistem baru untuk menyelesaikan masalahmasalah yang dihadapi oleh para pengguna aplikasi $e$-commerce. 
Pembuatan sistem ini bertujuan untuk menghasilkan sebuah sistem baru melalui sistem pengkodean komputerisasi menghasilkan interface yang user friendly. Implementasi ini bertujuan agar sistem yang dihasilkan dapat memberikan manfaat mengatasi persoalan yang terjadi dan menyelesaikan kelemahan yang terjadi pada aplikasi e-commerce lainnya. Untuk penerapannya yaitu dengan menggunakan cara secara berurutan (waterfall), dimana setiap tahapan harus diselesaikan terlebih dahulu secara penuh sebelum meneruskan ke tahapan berikutnya, dengan tujuan menghindari terjadinya pengulangan tahapan tersebut. Pemeliharaan bertujuan agar sistem dapat berjalan atau dioperasionalkan secara optimal dan sesuai dengan fungsinya. Tahap evaluasi dilakukan untuk memastikan bahwa pelaksanaan pengembangan sistem sesuai dengan rencana yang telah ditetapkan baik dari segi waktu, biaya maupun secara teknis.

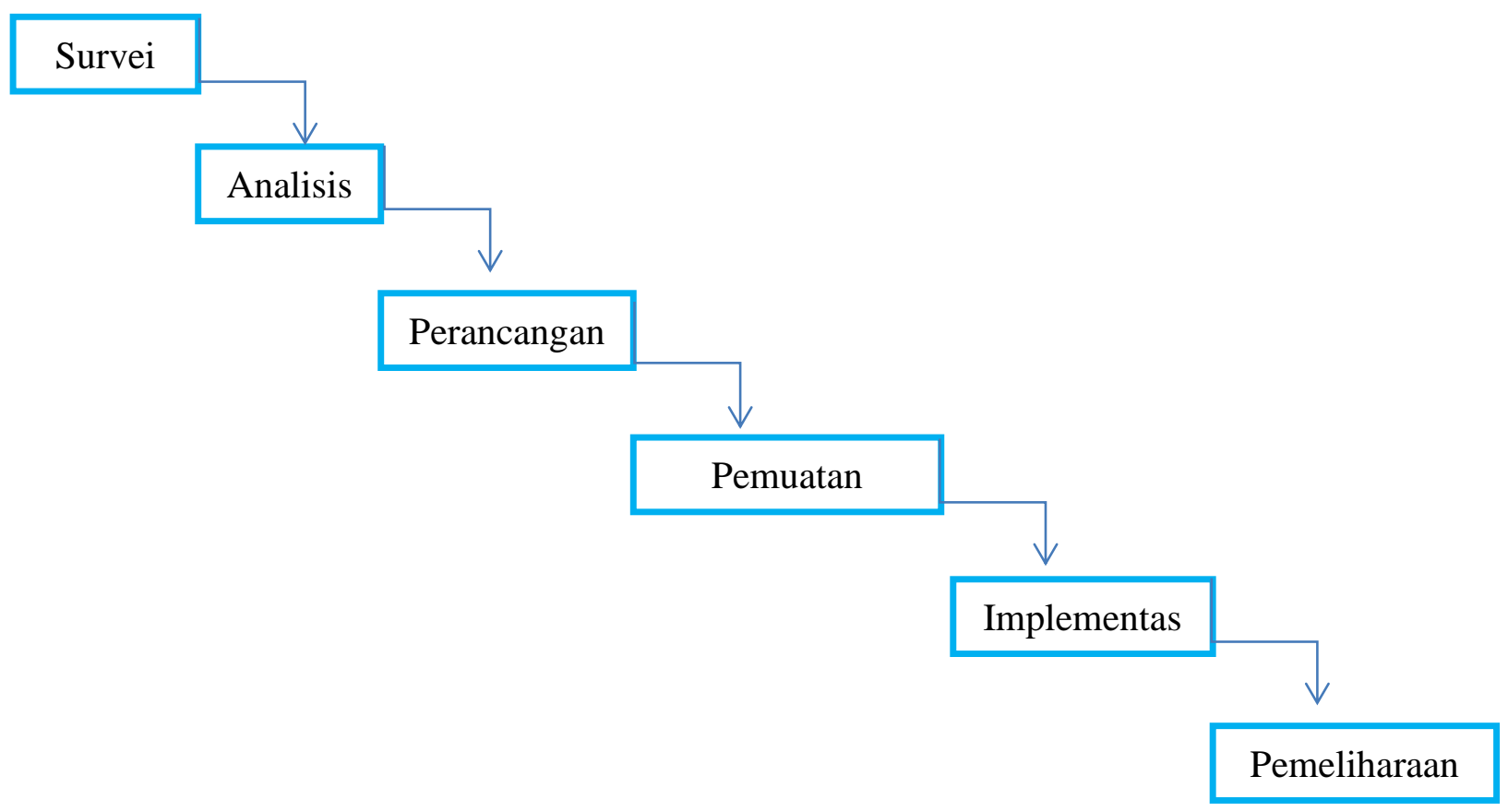

Gambar 1. Metode Waterfall

Perancangan sistem basis data menggunakan metode pendekatan terstruktur. Metode ini lebih menekankan pada aliran data, yaitu Data Flow Diagram (DFD). 
Data Akun

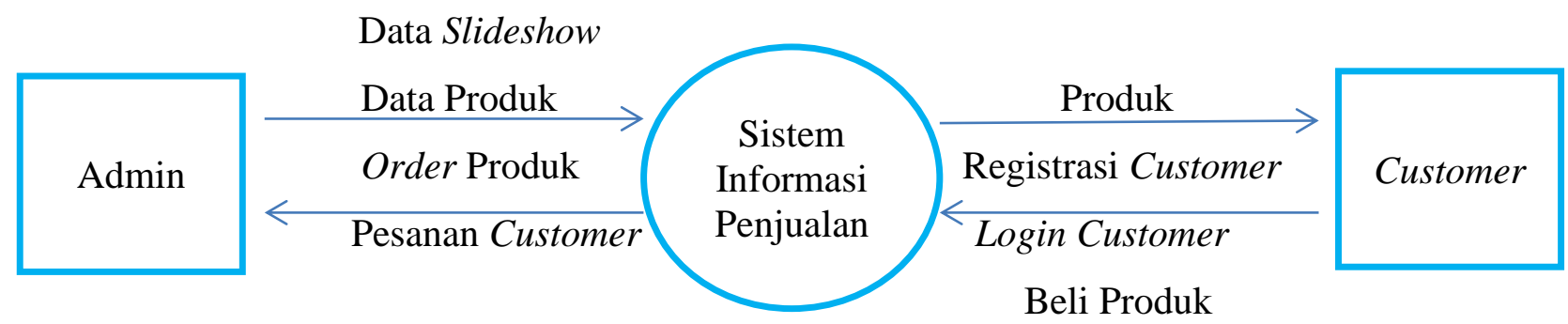

Pesan

Gambar 2.

Diagram Konteks Perancangan relasi antar tabel digunakan untuk merepresentasikan hubungan suatu tabel ke tabel lainnya yang berfungsi untuk mengatur operasi basis data.

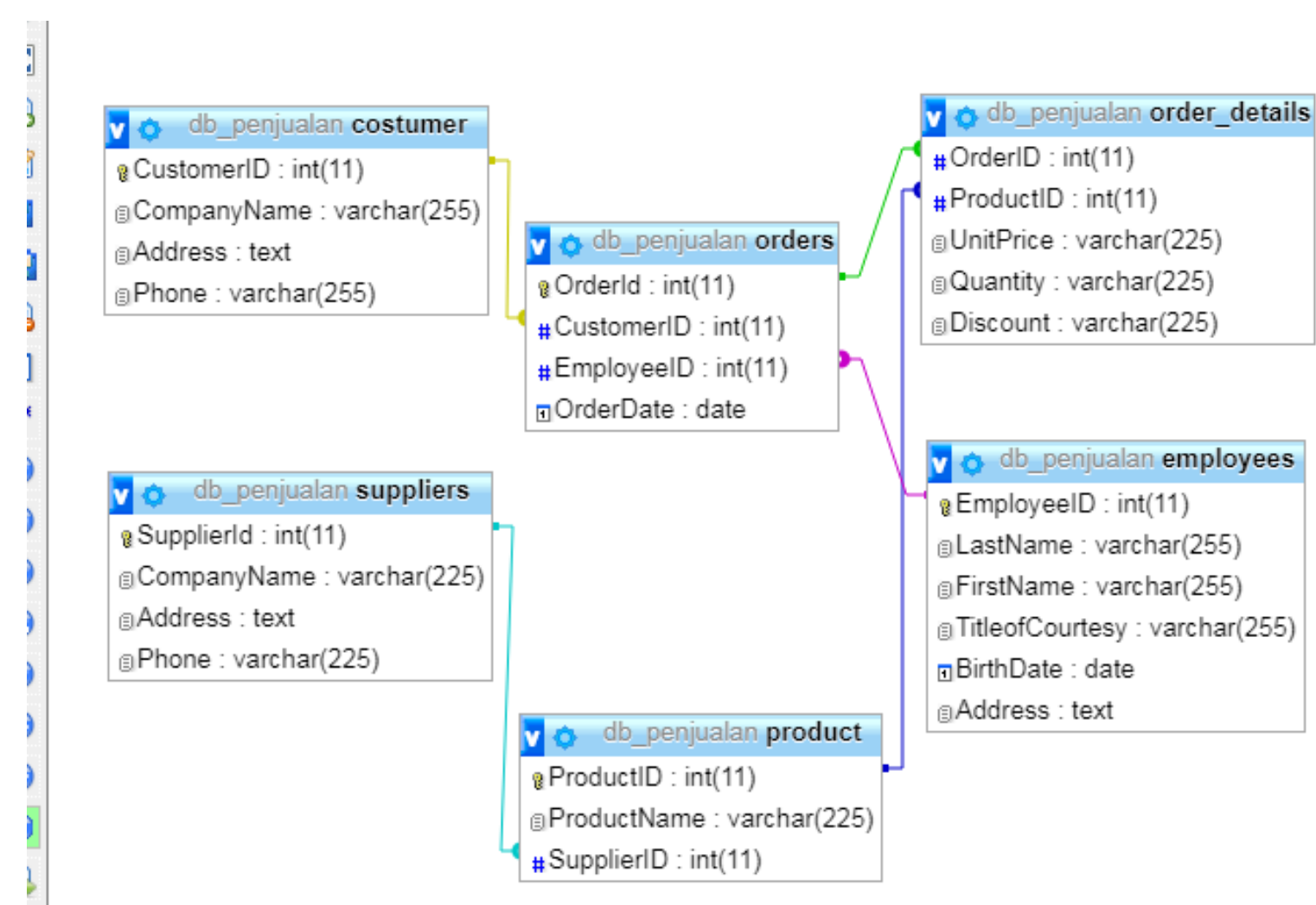

Gambar 3.

Relasi Antar Tabel 


\section{PEMBAHASAN}

Halaman utama pertama kali diakses oleh customer ketika mengunjungi website $e$-commerce ini dapat di akses di website atau download aplikasi langsung di App store atau google play.

A. Halaman utama toko produk
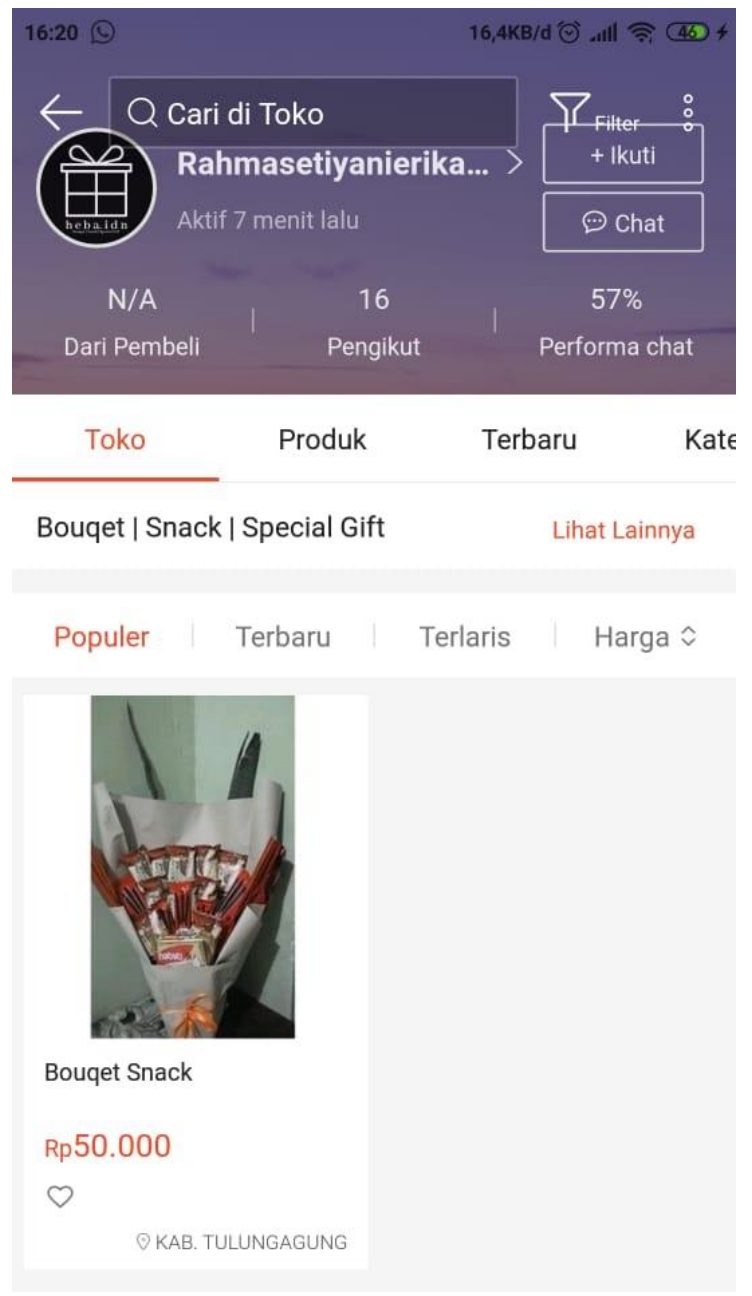

B. Halaman detail produk

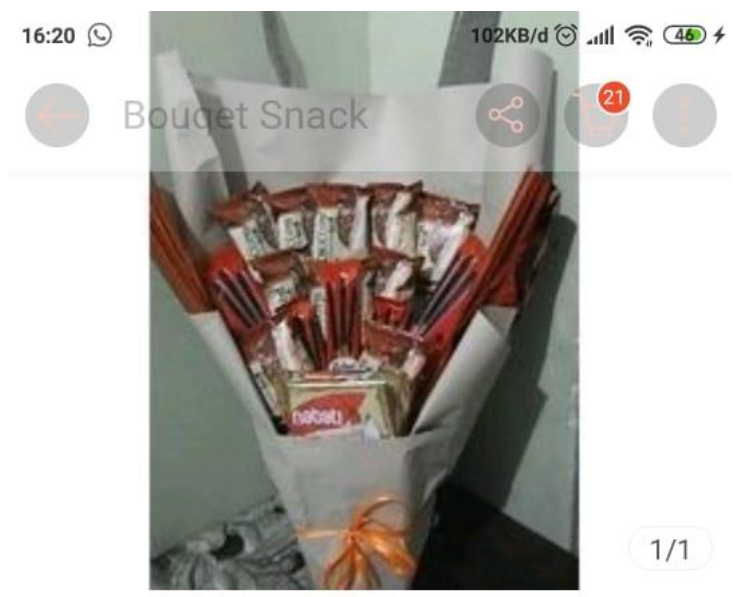

Bouqet Snack

\section{Rp50.000}

Belum ada penilaian 0 Terjual $\bigcirc \propto$

获 Pre-Order (dikirim dalam 7 hari)

68 Ongkos Kirim: Rp55.000 - Rp88.000

Kunjungi Toko

rahmasetiyanierika091

Aktif 6 menit lalu

Beli Sekarang 
C. Deskripsi produk

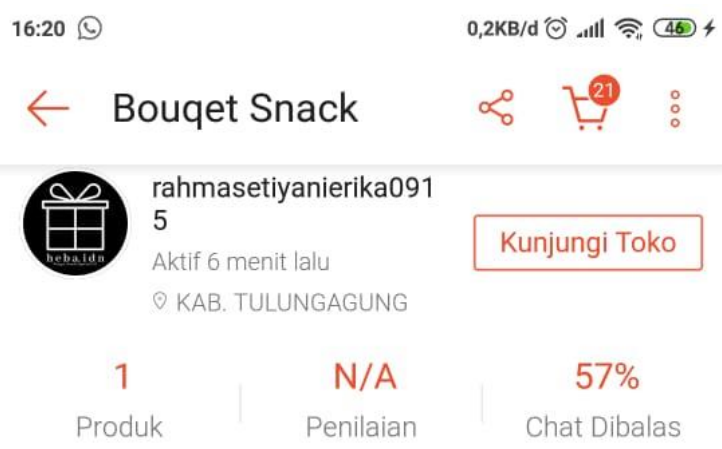

Rincian Produk (ㄴ) 30 hari

Stok 20

Merek Tidak Ada Merek

Dikirim Dari KAB. TULUNGAGUNG -

KEDUNGWARU, JAWA TIMUR, ID

Bouqe Snack isian by request bisa ya kak 후

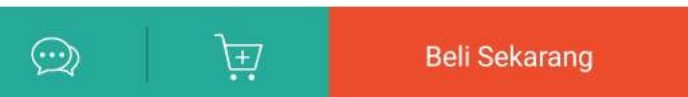

D. Halaman Chat kepada penjual

\section{6:43 (2)}

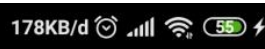

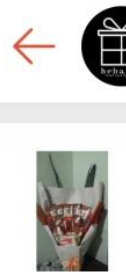

@heba.indonesia

:

No. Pesanan: 2106246JBOF77H

Total: Rp107.500

Belum Bayar

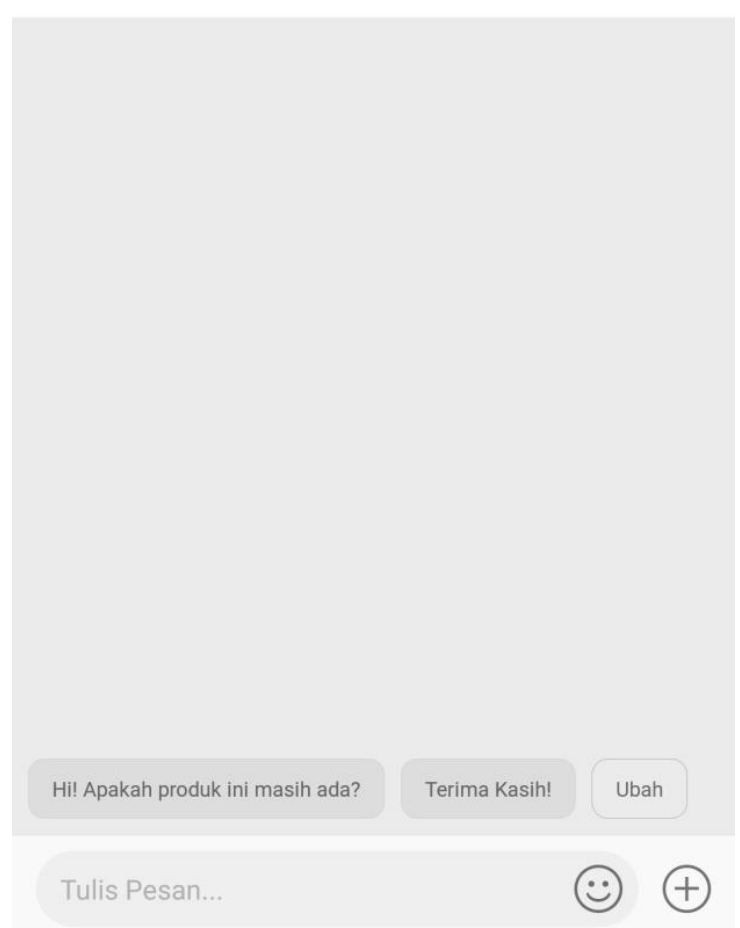


E. Halaman keranjang customer

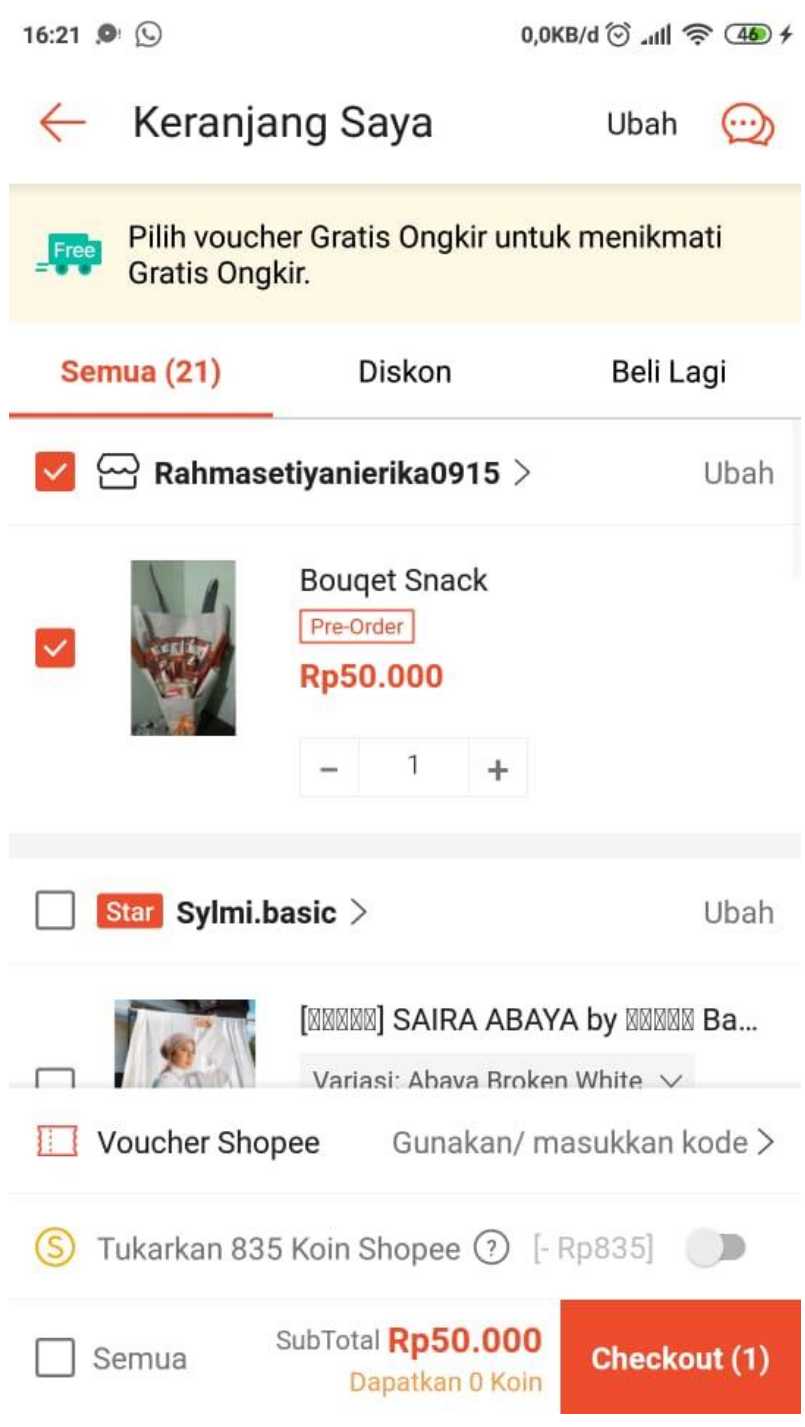

F. Halaman profil penjual

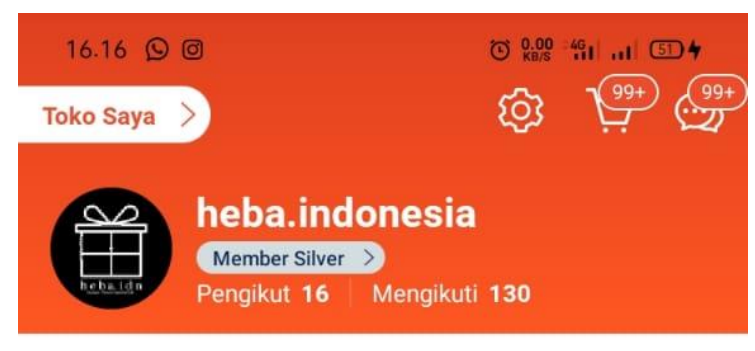

Beli

Postingan

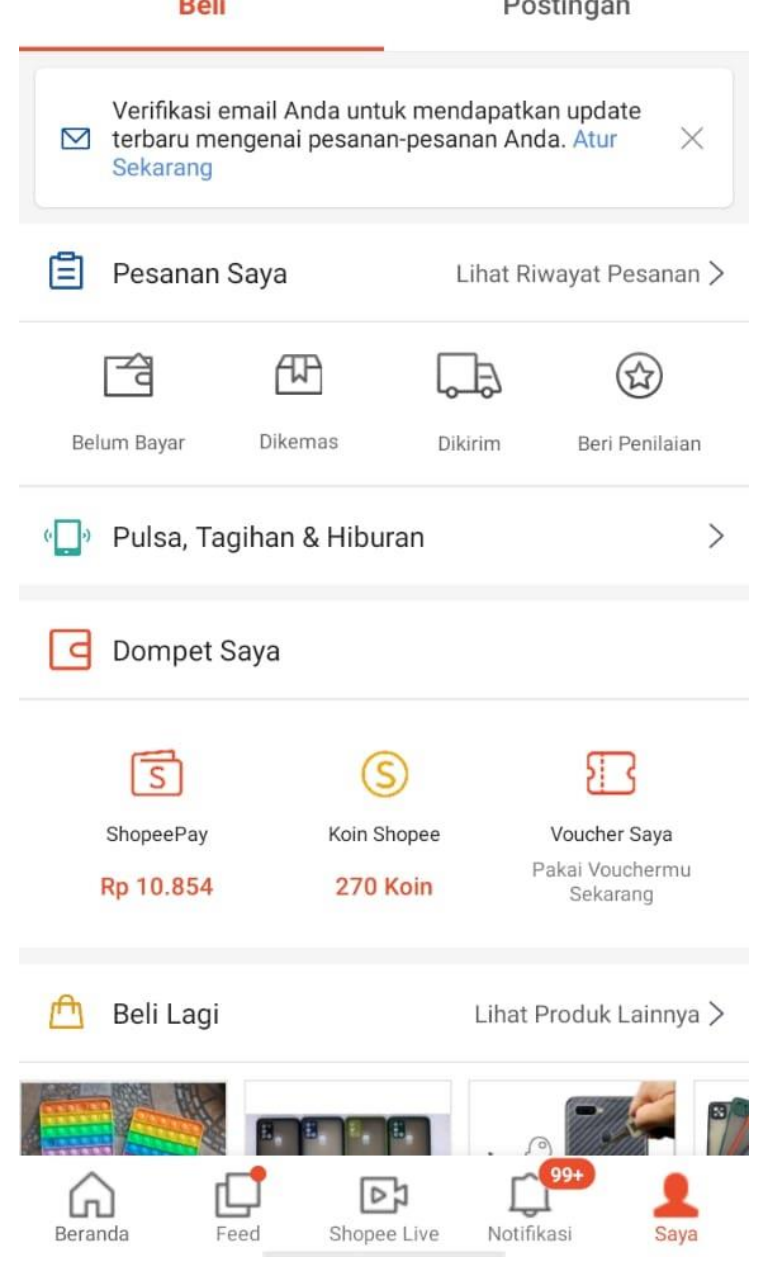


G. Rincian pesanan customer/data order

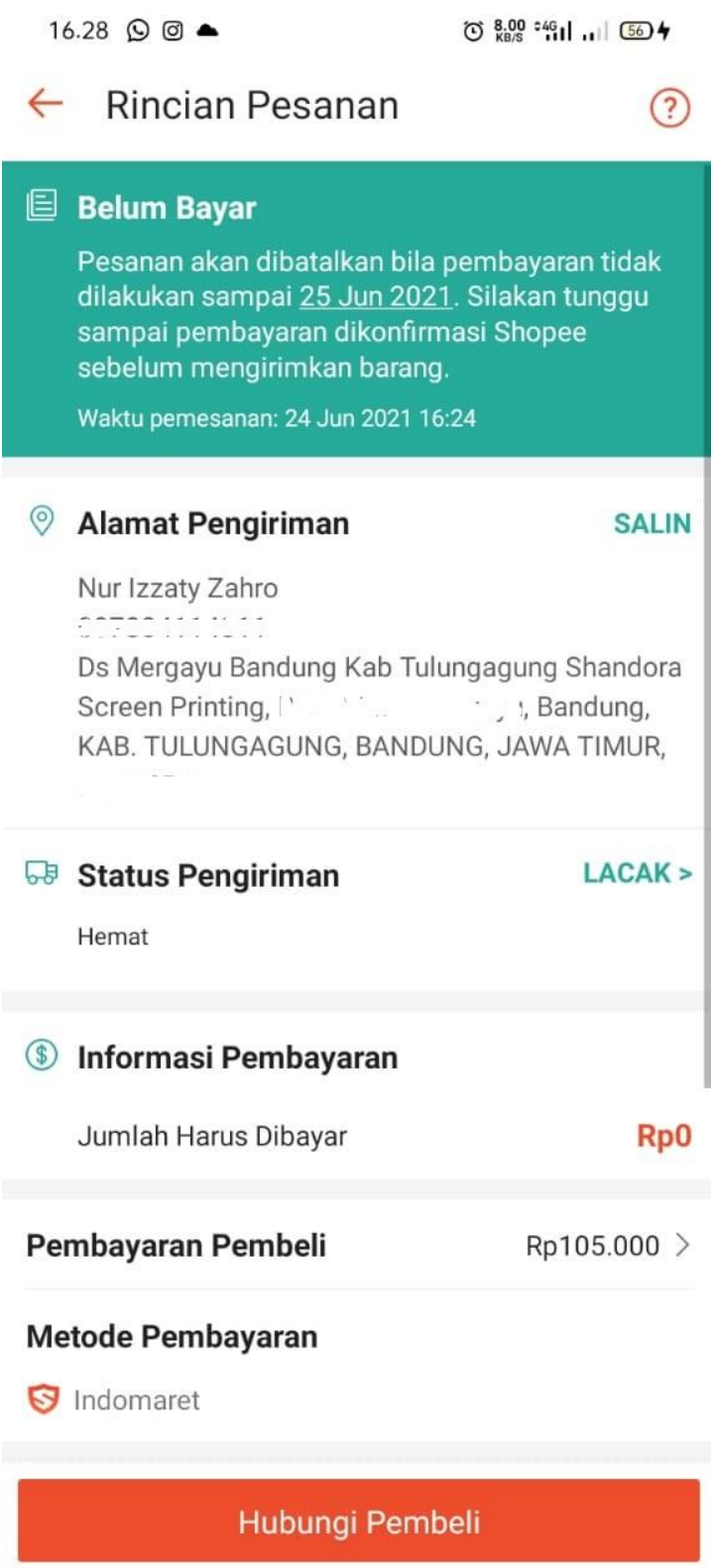

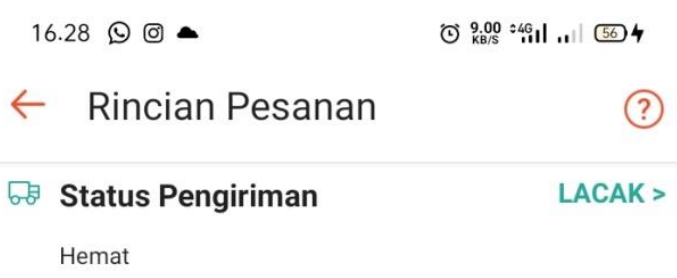

(\$) Informasi Pembayaran

Jumlah Harus Dibayar $\quad$ Rp0

\section{Pembayaran Pembeli \\ Rp105.000 >}

\section{Metode Pembayaran}

$\otimes$ Indomaret

nurizzaty_12

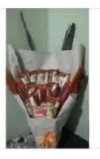

Pre-order Bouqet Snack

No. Pesanan

Waktu pemesanan

2106246JBOF77H SALIN

24 Jun 2021 16:24

Tambahkan Catatan

\%ubungi Pembeli

Hubungi Pembeli

H. Laporan penjualan

\begin{tabular}{|l|l|l|l|l|}
\hline No & Produk & Qty & Harga & Total \\
\hline 1 & Bucket Snack & 5 & 50000 & 250000 \\
\hline 2 & Snack Box & 3 & 45000 & 135000 \\
\hline 3 & Hampers hari Raya & 4 & 100000 & $\underline{400000}$ \\
\hline & & & & 785000 \\
\hline
\end{tabular}




\section{PENGUJIAN DAN HASIL}

Hasil dari penelitian ini dilakukan dengan beberapa metode penelitian yaitu dengan metode Black Box dan User Acceptance. Pengujian Black Box adalah pengujian dengan sistem hanya mengamati hasil eksekusi melalui data uji dan memeriksa fungsi dari software, sedangkan metode User Acceptance adalah proses pengujian yang dilakuan pengguna yang dimaksudkan untuk menhasilkan dokumen yang akan dijadikan bukti bahwa software atau perangkat lunak yang digunakan dan dikembangkan telah diterima oleh pengguna.

\section{A. PENGUJIAN BLACK BOX}

Pengujian Black Box yang dilakukan dapat ditampilkan sebagai berikut :

Tabel 1. Hasil pengujian Black Box

\begin{tabular}{|c|c|c|c|}
\hline Input & Proses & Output & Hasil uji \\
\hline Tombol simpan & $\begin{array}{l}\text { Pengguna } \\
\text { memasukkan data di } \\
\text { form yang telah } \\
\text { disediakan sistem } \\
\text { kemudian } \\
\text { melakukanpendaftaran } \\
\text { sesuai dengan } \\
\text { instruksi dari sistem. } \\
\text { Kemudian } \\
\text { menyimpan data-data } \\
\text { pengguna. }\end{array}$ & Data tersimpan & Sesuai \\
\hline Tombol hapus & $\begin{array}{l}\text { Pengguna } \\
\text { menggunakan tombol } \\
\text { hapus atau delete } \\
\text { apabila ada data yang } \\
\text { tidak perlu digunakan } \\
\text { di form atau jika } \\
\text { terdapat data yang } \\
\text { salah input }\end{array}$ & Data Hapus & Sesuai \\
\hline Tombol reset & $\begin{array}{l}\text { Pengguna mengeklik } \\
\text { tombol reset }\end{array}$ & Data reset & Sesuai \\
\hline
\end{tabular}




\begin{tabular}{|l|l|l|l|}
\hline Data perbaharui & $\begin{array}{l}\text { Pengguna mengeklik } \\
\text { tombol edit pada form } \\
\text { data untuk merubah } \\
\text { data yang diinginkan. } \\
\text { Kemudian klik tombol } \\
\text { perbaharui. }\end{array}$ & Data diperbaharui \\
\hline Tombol Cari & $\begin{array}{l}\text { Fitur sistem yang } \\
\text { digunakan untuk } \\
\text { pengguna mencari } \\
\text { barang atau fitur } \\
\text { dengan mengetikan } \\
\text { kata kunci ke kolom } \\
\text { yang disediakan }\end{array}$ & Sesuai \\
\hline
\end{tabular}

User Acceptance Testing adalah proses pengujian untuk mengumpulkan data dari objek apakah sistem tersebut memenuhi syarat yang diinginkan atau tidak. Dalam sistem software User Accetance Testing diguakan sebagai tahap akhir proyek yang sering digunakan untuk mengetahui audience atau pengguna merasakan kepuasan atau tidak terhadap sistem yang diujikan. Keterangan yang dgunakan adalah sebagai berikut :
a. Sangat setuju $=5$
b. Setuju sekali $=4$
c. Setuju $=3$
d. Cukup setuju $=2$
e. Tidak setuju $=1$ 
Anaisa hasil kuisioner yang dilakukan terhadap 10 orang responden pengguna aplikasi yang kami lakukan degan beberapa pertanyaan yang hasilnya sesuai dengan data berikut ini :

Tabel 2. Tabel hasil kuisioner

\begin{tabular}{|l|r|r|r|r|r|r|r|r|r|r|}
\hline Pertanyaan & $\mathbf{R}$ & $\mathbf{R}$ & $\mathbf{R}$ & $\mathbf{R}$ & $\mathbf{R}$ & $\mathbf{R}$ & $\mathbf{R}$ & $\mathbf{R}$ & $\mathbf{R}$ & $\mathbf{R}$ \\
\hline $\begin{array}{l}\text { Setujukah anda } \\
\text { dengan sistem } \\
\text { informasi } \\
\text { manajemen } \\
\text { berbasis } \text { - } \\
\text { commerce dalam } \\
\text { pengelolaan dan } \\
\text { pemasaran hasil } \\
\text { industri rumah } \\
\text { tangga? }\end{array}$ & 4 & 3 & 4 & 5 & 5 & 4 & 5 & 5 & 3 & 3 \\
\hline $\begin{array}{l}\text { Setujukah anda } \\
\text { dengan menu- } \\
\text { menu didalam } \\
\text { aplikasi ini? }\end{array}$ & 4 & 5 & 5 & 4 & 4 & 3 & 3 & 3 & 5 & 4 \\
\hline $\begin{array}{l}\text { Setujukah anda } \\
\text { tampilan dari } \\
\text { aplikasi ini mudah } \\
\text { dipahami? }\end{array}$ & 3 & 4 & 3 & 3 & 3 & 5 & 5 & 3 & 4 & 3 \\
\hline $\begin{array}{l}\text { Setujukah anda } \\
\text { aplikasi ini } \\
\text { menghasilkan } \\
\text { informasi yang } \\
\text { valid dan akurat? }\end{array}$ & 35 & 3 & 4 & 4 & 4 & 4 & 3 & 5 & 4 & \\
\hline Jumlah & 16 & 15 & 16 & 16 & 16 & 14 & 15 & 17 & 16 & 16 \\
\hline
\end{tabular}

Untuk mengetahui validitas dari aplikasi ini, perlu dilakukan penghitungan validitas, validitas yang dihitung adalah data hasil kuisioner karyawan, dan data terlampir di daftar lampiran, perhitungan data validitas menggunakan rumus:

$\operatorname{rxy}=\frac{\mathrm{n} \sum \mathrm{XY}-\left(\sum \mathrm{X}\right)\left(\sum \mathrm{Y}\right)}{\sqrt{\left\{\mathrm{n} \sum \mathrm{X} 2-\left(\sum \mathrm{X} 2\right) 2\right\}\left\{\mathrm{n} \sum \mathrm{Y} 2-\left(\sum \mathrm{Y} 2\right) 2\right\}}}$

Keterangan :

rxy : Koefisien korelasi

$\mathrm{n}$ : Jumlah responden

$\mathrm{x}$ : Skor tiap pertanyaan

y : Skor hasil seluruh pertanyaan 
Lalu untuk menguji signifikan hasil korelasi, digunakan uji-t. Adapun kriteria untuk menentukan signifikan dengan membandingkan nilai t-hitung dan t-tabel. Jika t-hitung $>\mathrm{t}-$ tabel, maka dapat disimpulkan bahwa pertanyaan tersebut valid. Rumus mencari t-hitung yang digunakan adalah :

$$
t \text { hitung }=\frac{\operatorname{rxy} \sqrt{n}-2}{\sqrt{1}-\mathrm{rxy} 2}
$$

Tabel 3. Perhitungan Validitas

\begin{tabular}{|r|r|r|r|r|r|r|r|r|r|r|r|r|r|r|r|}
\hline Responden & R 1 & R 2 & $\mathbf{R} 3$ & $\begin{array}{l}\mathbf{R} \\
\mathbf{4}\end{array}$ & $\begin{array}{l}\mathbf{R} \\
\mathbf{5}\end{array}$ & $\begin{array}{l}\mathbf{R} \\
\mathbf{6}\end{array}$ & $\begin{array}{l}\mathbf{R} \\
\mathbf{7}\end{array}$ & $\begin{array}{l}\mathbf{R} \\
\mathbf{8}\end{array}$ & $\begin{array}{l}\mathbf{R} \\
\mathbf{9}\end{array}$ & $\begin{array}{l}\mathbf{R} \\
\mathbf{1 0}\end{array}$ & $\mathbf{r x y}$ & $\begin{array}{l}\mathbf{t} \\
\text { hitung }\end{array}$ & $\begin{array}{l}\mathbf{t} \\
\text { tabel } \\
\mathbf{9 5 \%} \\
\mathbf{1 0}\end{array}$ & $\begin{array}{l}\text { Ket } \\
\text { Jumlah } \\
\text { valid }\end{array}$ \\
\hline $\begin{array}{r}\text { Pertanyaan } \\
\text { ke 1 }\end{array}$ & 4 & 3 & 4 & 5 & 5 & 4 & 5 & 5 & 3 & 3 & 0.241 & 0.702 & & & \\
\hline $\begin{array}{r}\text { Pertanyaan } \\
\text { ke 2 }\end{array}$ & 4 & 5 & 5 & 4 & 4 & 3 & 3 & 3 & 5 & 4 & 0.161 & 0.462 & 1.740 & Valid & 4 \\
\hline $\begin{array}{r}\text { Pertanyaan } \\
\text { ke 3 }\end{array}$ & 3 & 4 & 3 & 3 & 3 & 5 & 5 & 3 & 4 & 3 & 0.033 & 0.095 & & & \\
\hline $\begin{array}{r}\text { Pertanyaan } \\
\text { ke 4 }\end{array}$ & 35 & 3 & 4 & 4 & 4 & 4 & 3 & 5 & 4 & 4 & 0.643 & 2.374 & & & \\
\hline Total & 16 & 15 & 16 & 16 & 16 & 14 & 15 & 17 & 16 & 16 & & & & & \\
\hline
\end{tabular}

Hasil yang didapat dari perhitungan tersebut adalah bahwa 4 pertanyaan bernilai valid dan tidak ada pertanyaan bernilai tidak valid. Selanjutnya akan dilakukan uji reliabilitas. Dalam melakukan uji reliabilitas ada beberapa langkah yang harus dilakukan yaitu sebagai berikut :

1. Mencari harga variasi total dengan rumus :

$\sigma_{\mathrm{b}}^{2}=\frac{\sum \mathrm{X} 2 \frac{-\left(\sum \mathrm{X}\right) 2}{\mathrm{n}}}{\mathrm{n}}$

2. Menentukan besar varians total dengan rumus :

$\sigma_{\mathrm{t}}^{2}=\frac{\sum \mathrm{X} 2 \frac{-\left(\sum \mathrm{X}\right) 2}{\mathrm{n}}}{\mathrm{n}}$

3. Menghitung koefisien reliabilitas dengan rumus Alpha :

$r_{11}==[k k-1]\left[1-\frac{\mathrm{b} \sigma 2}{\sigma 2 \mathrm{t}}\right]$ 
Maka perhitungannya sebagai berikut :

Tabel 4 Perhitunan Reabilitas

\begin{tabular}{|r|c|c|c|c|c|c|c|c|c|c|c|c|c|c|}
\hline Responden & $\mathbf{R}$ & $\mathbf{R}$ & $\mathbf{R}$ & $\mathbf{R}$ & $\mathbf{R}$ & $\mathbf{R}$ & $\mathbf{R}$ & $\mathbf{R}$ & $\mathbf{R}$ & $\mathbf{R}$ & $\mathbf{V a r}$ & VAR & VAR & RELIABILITAS \\
& $\mathbf{1}$ & $\mathbf{2}$ & $\mathbf{3}$ & $\mathbf{4}$ & $\mathbf{5}$ & $\mathbf{6}$ & $\mathbf{7}$ & $\mathbf{8}$ & $\mathbf{9}$ & $\mathbf{1 0}$ & $\mathbf{I t e m}$ & ITEM & TOTAL & \\
\hline $\begin{array}{r}\text { Pertanyaan } \\
\text { ke 1 }\end{array}$ & 4 & 3 & 4 & 5 & 5 & 4 & 5 & 5 & 3 & 3 & 0.767 & & & \\
\hline $\begin{array}{r}\text { Pertanyaan } \\
\text { ke 2 }\end{array}$ & 4 & 5 & 5 & 4 & 4 & 3 & 3 & 3 & 5 & 4 & 0.667 & 2.522 & 4.678 & 0.654 \\
\hline $\begin{array}{r}\text { Pertanyaan } \\
\text { ke 3 }\end{array}$ & 3 & 4 & 3 & 3 & 3 & 5 & 5 & 3 & 4 & 3 & 0.622 & & & \\
\hline $\begin{array}{r}\text { Pertanyaan } \\
\text { ke 4 }\end{array}$ & 35 & 3 & 4 & 4 & 4 & 4 & 3 & 5 & 4 & 4 & 0.544 & & & \\
\hline Total & 16 & 15 & 16 & 16 & 16 & 14 & 15 & 17 & 16 & 16 & & & & \\
\hline
\end{tabular}

Maka akan di ketahui nilai Alpha Cronbach adalah 0,654 dengan jumlah pertanyaan 4 buah. Alpha Cronbach $=0,654$ terletak diantara 0,60 hingga 0,80 sehingga tingkat reliabilitasnya adalah reliabel. Untuk lebih jelasnya tingkat reliabilitas berdasarkan nilai Alpha dapat dilihat pada tabel dibawah ini.

Tabel 5. Tingkat reabilitas alpha

\begin{tabular}{|c|c|}
\hline Alpha & Tingkat Reabilitas \\
\hline $\mathbf{0 , 0 0}$ s/d 0,20 & Kurang Reliabel \\
\hline$>\mathbf{0 , 2 0}$ s/d $\mathbf{0 , 4 0}$ & Agak Reliabel \\
\hline$>\mathbf{0 , 4 0}$ s/d $\mathbf{0 , 6 0}$ & Cukup Reliabel \\
\hline$>\mathbf{0 , 6 0}$ s/d $\mathbf{0 , 8 0}$ & Reliabel \\
\hline $\mathbf{> 0 , 8 0}$ s/d $\mathbf{1 , 0 0}$ & Sangat Reliabel \\
\hline
\end{tabular}

\section{KESIMPULAN}

Berdasarkan dari hasil penelitian yang kami lakukan dapat diambil kesimpulan bahwa:

1. Sistem Informasi Manajemen yang dilakukan dengan berbasis pada e-commerce memberikan manfaat yang besar bagi pemasaran suatu produk

2. Selain memudahkan untuk penjual dalam memasarkan, e-commerce juga lebih memudahkan customer dalam mencari barang dan bisa juga langsung 
membandingkan barang atau suatu produk yang sama namun dengan harga yang berbeda di setiap tokonya tanpa harus susah-susah bertanya kepada seller atau penjualnya secara langsung. Selain itu, pembeli juga tidak perlu repot untuk keluar rumah untuk membeli produk. Cukup dirumah pesan barang melalui aplikasi maka barang akan sampai. Belum lagi jika terdapat diskon sehingga semakin menarik konsumen untuk membeli barang melalui e-commerce

3. Pengujian sampel menggunakan metode black box atau user acceptance sehingga mendapatkan hasil yang memuaskan tentang sistem informasi manajemen.

\section{DAFTAR REFERENSI}

Rachmad Gesah and Mukti Prabowo, 'Manajemen Strategi Penulis: Rachmad Gesah Mukti Prabowo', INA-Rxiv Paper, 2019.

Riza Kholdani , A.F \& Puspitasari, D.I. (2018) . Sistem Informasi Manajemen Untuk Meningkatkan Daya Saing Industri Rumah Tangga , 9(2) ,1-9 .

Arief, M. R. (2011). Pemrograman Web Dinamis Menggunakan PHP dan MySQL. Yogyakarta: Andi.

Dillman, D. A., Smyth, J. D., \& Christian, L. M. (2014). Internet, phone, mail, and mixedmode surveys: the tailored design method. John Wiley \& Sons.

Hasanah, U. (2013). Sistem Informasi Penjualan On_Line Pada Toko Kreatif Suncom Pacitan. IJNS-Indonesian Journal on Networking and Security, 4(3).

Irmawati, D. (2011). Pemanfaatan e-commerce dalam dunia bisnis. Orasi Bisnis, 13-20.

Jauhari, J. (2014). Upaya pengembangan usaha kecil dan menengah (UKM) dengan memanfaatkan e-commerce. Jurnal Sistem Informasi, 2(1).

Kosasi, S. (2015). Perancangan Sistem ECommerce Untuk Memperoleh Pasar Produk Oleholeh Khas Pontianak. SNASTIA, 110-119.

Maryama, S. (2013). Penerapan E-Commerce Dalam Meningkatkan Daya Saing Usaha. Liquidity, 73-79.

Maharsi, S. (2004). Pengaruh Perkembangan Teknologi Informasi Terhadap Bidang Akuntansi Manajemen. Jurnal Akuntansi dan keuangan, 2(2), pp-127.

Saputro, H. W. (2007). Pengertian Website, Web Hosting dan Domain Name.

Setiyadi, A., \& Triyono, R. A. (2014). Pembangunan Website E-Commerce Dengan Sistem Informasi Transaksi Berbasis SMS Gateway PAda Toko Aska. IJNS, 30-36 